\title{
Lye-Peeling of Green Papaya (Carica papaya L.)
}

\author{
L. E. Cancel, I. Herndindez, and E. Rodriguez-Sosa ${ }^{1}$
}

\section{INTRODUCTION}

Great efforts are being made presently to bring the papaya fruit of Puerto Rico into industrialization. Many papaya products can be processed into regular consumer items such as our traditional sliced papaya in extra heavy syrup ( $\mathrm{Ca} 62^{\circ}$ Brix), papaya canned in light, medium or heavy syrup, and glazed papaya slices. Suitable techniques for removing the peel from green papayas obviously are necessary for such processing. Canners now have the peel removed from the fruit by hand or by immersing the fruit in hot lye solutions.

This study was made to evaluate some of the economic factors in the lye-peeling process such as the most effective concentrations of lye, the length of time required for adequate peeling at different lye concentrations, and also to determine residual alkalinity and possible textural changes in the resulting papaya pulp. The results of this study are reported below.

\section{REVIEW OF LITERATURE}

Woodroof $(1)^{2}$ stated that the lye peeling method is suitable for peeling all sizes, shapes and varieties of most fruits, vegetables, and root crops, but that the appropiate relation of lye concentration, temperature of the solution, and time of immersion should be established for each product.

Mazzola (2) peeled potatoes in 10 seconds by dipping them in a 53-percent lye solution at $300^{\circ} \mathrm{F}$. with only 7-percent waste. Greig and Manchester (3) recommended a method which requires an 8-minute immersion in a 15-percent lye solution at $155^{\circ} \mathrm{F}$. Dunlop (4) reported that he had peeled potatoes satisfactorily by dipping them for 2 minutes in a boiling 14-percent lye solution. This shows the need for exact knowledge of the appropriate relationships between the concentration and temperature of the solution and immersion time.

Lye peeling of many fruits and vegetables has been studied by a number of investigators. Woodroof and Atkinson ( 5 ) peeled sweetpotatoes by dipping the tubers in a boiling 10-percent lye solution for five minutes. Beets (6) can be lye-peeled by immersing the roots for three minutes in a boiling 7-percent lye solution. Stateler (7) obtained well-peeled carrots by

1 Food Technologist, Assistant Chemical Engineer, and Research Assistant, respectively, Food Technology Laboratory, Agricultural Experiment Station, Mayagũez Campus, University of Puerto Rico, Río Piedras, P.R.

2 Italic numbers in parentheses refer to Literature Cited, p. 27. 
dipping them for 70 seconds in an 18-percent lye solution at $218^{\circ} \mathrm{F}$. It has been reported (6) that carrots are well peeled by immersing them for $2 \frac{1}{2}$ minutes in a boiling 3-percent lye solution. No information occurs in the literature, apparently, concerning lye-peeling of green papayas.

\section{MATERIALS AND METHODS}

PAPAYAS

Commercially grown varieties of green papayas (Carica papaya L.) were used in all the experiments. It must be noted, however, that commercial varieties of papaya grown in Puerto Rico are not of a fixed type. They vary in size, shape, color, and thickness of pulp. The fruits studied were obtained from an experimental plot at the Gurabo Substation and from commercial plantations in the area of Isabela. The fruits for the lye-peeling studies were harvested completely green. The average weight of the fruit used in these experiments varied from 3 to 5 pounds.

\section{LYE SOLUTION}

Lye solutions were prepared from 76-percent pure sodium hydroxide flakes. The sodium hydroxide concentrations in these solutions varied from 92 to $104 \mathrm{~g}$. per liter for the 10-percent solution, 152 to $180 \mathrm{~g}$. per liter for the 15-percent solution, and 212 to $220 \mathrm{~g}$. per liter for the 20-percent solution. The concentration of the solutions was readjusted periodically during the experiments. Twenty-five $\mathrm{ml}$. of the lye solutions were titrated with 4 $N$ hydrochloric acid. Flakes were added until the titration value indicated the concentration was within an acceptable range in the desired percent by weight concentration.

Boiling temperatures for the several lye solutions were $216^{\circ}, 221^{\circ}$, and $226^{\circ} \mathrm{F}$., for the 10-, 15-, and 20-percent by weight concentrations, respectively.

In this study, 125 pounds of solution were prepared for each batch because the capacity of the lye-peeler was limited to 14 to 17 gallons of lye solution.

\section{BHEAR-PRESS DETERATNATION}

After the papaya was peeled and washed, it was diced in a hand-operated mechanical dicer equipped with a 1-inch die. The resulting papaya cubes were then stacked in the sample holder of a Lee-Kramer shear-press. For these determinations the instrument was adjusted to the 2,000-pound range and to a velocity of $1.45 \mathrm{~mm}$./second. The sample holder in this instrument takes 8 ounces of 1 -inch diced cubes. 
LYE-PEELING

The lye peeler used consisted of a rectangular steel vessel divided into two chambers. Each chamber had a perforated basket which provided for a rapid separation of the fruit from the lye solution and quick immersion in fresh water. The lye solution was heated by a steam coil of high heating capacity.

The lye solution in this study was heated to the boiling point, then the papayas were immersed in the boiling solution for the predetermined period of time. After the specific time elapsed, the papayas were dumped into fresh cold water for fast cooling. The hydrolyzed tissue around the fruit was removed with water sprays until all softened tissue disappeared and the reaction of the surface of the peeled papaya was no longer alkaline to a phenolphthalein indicator.

\section{RESULTS AND DISCUSSION}

RELATION BETWEEN TIME OF IMMERSION AND THE LYE SOLUTION CONCENTRATION ON THE LYE-PETLING OPFRATION

A series of experiments was conducted using lye solutions of 10-, 15-, and 20-percent lye by weight. The time of immersion of the papaya fruit varied from 2 to 7 minutes, 2 to 6 minutes, and 2 to 5 minutes, respectively, for each lye concentration. The average values and ranges for three replications are shown in table 1. The data presented reveals that a good peeling operation may be obtained from any of the three following combined boiling lye solution treatments: 6 minutes in a 10-percent solution, 4 minutes in a 15-percent solution, and 3 minutes in a 20-percent solution.

The results of the experiments to determine possible undesirable effects on the papaya pulp with respect to acidity and hardness are shown in table 2. The average values for hardness and acidity of the hand-peeled papaya pulp, compared with the values of lye-peeled papaya pulp, show them to be quite similar. Average values for these two properties for handpeeled papaya pulp were 0.42 percent for total acidity and 6.62 square inches for hardness. The titrable acidity values for the lye-peeled papaya pulp expressed as citric acid, which range from 0.030 to 0.059 percent, do not show any specific trend as compared with 0.42 percent found for handpeeled pulp. The average hardness value of 6.62 square inches found for hand-peeled papaya pulp is within the range obtained for the lye-peeled papaya pulp, which varied from 5.7 to 6.8 square inches.

\section{PEELING CAPACITY OF THE BOILING LYE BOLUTIONS}

A series of experiments was performed to determine the peeling capacity of the boiling lye solutions under study. The conditions of the experiments 
TABLE 1.-Relation between time of immersion and lye solution concentration on the effectiveness of the lye-peeling operation of green papayas

\begin{tabular}{|c|c|c|c|c|}
\hline \multirow{2}{*}{$\begin{array}{l}\text { Iye solution } \\
\text { concentration } \\
\text { (percent/ } \\
\text { weight) }\end{array}$} & \multirow{2}{*}{$\begin{array}{l}\text { Time of } \\
\text { immersion in the } \\
\text { lye solution }\end{array}$} & \multirow{2}{*}{$\begin{array}{l}\text { Visual craluation of } \\
\text { the peeling action }\end{array}$} & \multicolumn{2}{|c|}{$\begin{array}{l}\text { Loss in weight of the } \\
\text { whole fruit in lye peeling }\end{array}$} \\
\hline & & & Average & Range \\
\hline 10 & $\begin{array}{l}\text { Minutes } \\
2 \\
4 \\
5 \\
6 \\
7\end{array}$ & $\begin{array}{l}\text { Questionable' } \\
\text { do. } \\
\text { do. } \\
\text { Good? } \\
\text { Very good' }\end{array}$ & $\begin{array}{c}\text { Percent } \\
4.4 \\
7.2 \\
10.5 \\
13.2 \\
11.0\end{array}$ & $\begin{array}{c}\text { Percent } \\
3.0-5.7 \\
6.2-8.06 \\
9.86-11.4 \\
11.8-14.52 \\
9.84-12.12\end{array}$ \\
\hline 15 & $\begin{array}{l}2 \\
4 \\
5 \\
6\end{array}$ & $\begin{array}{l}\text { Questionable } \\
\text { Good } \\
\text { Very good } \\
\quad \text { do. }\end{array}$ & $\begin{array}{r}6.5 \\
10.5 \\
12.0 \\
15.5\end{array}$ & $\begin{array}{c}6.1-7.0 \\
10.3-11.1 \\
11.6-12.3 \\
14.3-16.7\end{array}$ \\
\hline 20 & $\begin{array}{l}2 \\
3 \\
4 \\
5\end{array}$ & $\begin{array}{l}\text { Questionable } \\
\text { Good } \\
\text { Very good } \\
\text { do. }\end{array}$ & $\begin{array}{r}5.5 \\
12.1 \\
15.6 \\
14.4\end{array}$ & $\begin{array}{l}1.82-9.10 \\
12.0-12.2 \\
14.3-17.02 \\
12.0-15.9\end{array}$ \\
\hline
\end{tabular}

1 Questionable-large unpeeled spots or many small unpeeled spots remained.

2 Good-one or two small unpeeled spots remained which could be easily removed in a trimming operation.

- Very good-completely peeled.

TABLI 2.-Effect on hardness and titrable acidity of the papaya pulp when lye-peeled under one of the recommended conditions

\begin{tabular}{|c|c|c|c|c|c|}
\hline \multirow{2}{*}{$\begin{array}{c}\text { Lye solution } \\
\text { concentration } \\
\text { (percent/weight) }\end{array}$} & \multirow{2}{*}{$\begin{array}{l}\text { Time of } \\
\text { immersion } \\
\text { in the } \\
\text { lye solution }\end{array}$} & \multirow{2}{*}{$\begin{array}{c}\text { Weight lost } \\
\text { by the whole } \\
\text { fruit on } \\
\text { lye-peeling }\end{array}$} & \multicolumn{2}{|c|}{ Shear-press determination } & \multirow{2}{*}{$\begin{array}{l}\text { Titrable acidity } \\
\text { (calculated } \\
\text { as citric acid) }\end{array}$} \\
\hline & & & $\begin{array}{l}\text { Maximum } \\
\text { inflection } \\
\text { on curve }\end{array}$ & $\begin{array}{l}\text { Ares under } \\
\text { the curve }\end{array}$ & \\
\hline & Minules & Percent & Units & Square inches & Percent \\
\hline 10 & 6 & 15.1 & 1700 & 6.8 & 0.057 \\
\hline 10 & 6 & 14.5 & 1770 & 6.5 & .050 \\
\hline 10 & 6 & 12.9 & 1670 & 6.0 & .059 \\
\hline 15 & 4 & 11.1 & 1820 & 6.7 & .055 \\
\hline 15 & 4 & 12.2 & 1740 & 6.6 & .030 \\
\hline 15 & 4 & 11.6 & 1580 & 5.9 & .039 \\
\hline 15 & 4 & 13.2 & 1500 & 5.7 & .038 \\
\hline 20 & 3 & 9.8 & 1660 & 6.0 & .034 \\
\hline 20 & 3 & 11.6 & 1680 & 6.5 & .060 \\
\hline
\end{tabular}


were: A 6-minute immersion of the fruit in a 10-percent boiling lye solution, a 4-minute immersion in a 15-percent boiling lye solution, and a 3-minute immersion in a 20-percent boiling lye solution. The solution in the lye peeler was maintained at the 16-gallon level for all experiments. Table 3 shows the data obtained.

The data shows that a batch lye-peeling operation, in which a pound of papaya per gallon of lye solution relationship is maintained, results in a peeled fruit that can at least be evaluated as "good". The data also shows that the surface area of fruits being so peeled has an effect on the quality of the operation. When peeling 20 pounds of papaya, represented by a large number of fruits in $\mathbf{1 6}$ gallons of lye solution, the treatment results normally in peeled papayas which are evaluated as "questionable". However, when the 20 pounds of papaya are represented by a small number of fruits, the peeling operation results in one that may be classified as "good". The results presented in table 3 tend to show that the relation between the volume of boiling lye solution to weight of papaya is dramatically affected by the relation of the volume of lye solution to the surface area of the papayas being peeled.

\section{HAND-PEELING OF PAPAYA FRUIT}

A series of experiments were performed in which hand-peeled papayas were used. The results are shown in table 4. Hand peeling of fruits and vegetables obviously is a high labor-consuming operation; also, the quality of hand peeled papaya fruit and the quantity of waste are uncertain.

Table 4 shows that the loss as peel varied from 13.2 to 19.8 percent, or an average of 16.1 percent. The total combined loss as stems, seeds and peel fluctuated from 19.8 to 30.7 percent, or an average of 24.5 percent.

Table 5 shows the results of a series of pilot plant runs when papayas were lye-peeled using a 15-percent lye solution concentration and a 5-minute immersion. When the results obtained from a hand-peeling operation (table 4) are compared with those from a pilot plant lye-peeling operation (table 5) the difference in total percent lost in weight is very small with the added advantage of a low labor cost such as the lye-peeling method provides.

\section{SUMMARY}

A good lye-peeling operation may be obtained when whole green papayas are peeled under any of the following three combined treatments: 6 minutes in a 10-percent boiling lye solution, 4 minutes in a 15-percent boiling lye solution, and 3 minutes in a 20-percent boiling lye solution. The average weight lost as peel for each of the above treatments was 14.2, 11.6, and 11.5 percent, respectively. Changes in the titrable acidity and hardness of the pulp in lye-peeled papayas fell within the values obtained in hand-peeled 
TABLE 3.-Determination of ratio of papaya fruit to lye solution for proper peeling action

\begin{tabular}{|c|c|c|c|c|c|c|c|}
\hline \multirow{2}{*}{$\begin{array}{c}\text { Lye } \\
\text { solution } \\
\text { concentra- } \\
\text { tion } \\
\text { (percent/ } \\
\text { weight) } \\
\end{array}$} & \multirow{3}{*}{$\begin{array}{c}\begin{array}{c}\text { Time of } \\
\text { immersion } \\
\text { in lye } \\
\text { solution }\end{array} \\
\text { Minules } \\
6\end{array}$} & \multirow{3}{*}{$\begin{array}{c}\begin{array}{c}\text { Boiling } \\
\text { temperature } \\
\text { of lye } \\
\text { solution }\end{array} \\
216^{\circ} \mathrm{F} .\end{array}$} & \multicolumn{2}{|c|}{$\begin{array}{l}\text { Weight of } \\
\text { papaya } \\
\text { fruit used }\end{array}$} & \multirow{2}{*}{$\begin{array}{c}\begin{array}{c}\text { Number of } \\
\text { fruits used } \\
\text { in trial }\end{array} \\
\text { Units }\end{array}$} & \multirow{2}{*}{$\begin{array}{c}\begin{array}{c}\text { Weight lost } \\
\text { by whole } \\
\text { fruit in } \\
\text { lye-peeling }\end{array} \\
\text { Percent }\end{array}$} & \multirow[t]{2}{*}{$\begin{array}{l}\text { Visual evaluation } \\
\text { of peeling action }\end{array}$} \\
\hline & & & Pounsds & Ounces & & & \\
\hline 10 & & & $\begin{array}{r}5 \\
5 \\
8 \\
8 \\
11 \\
11 \\
14 \\
14 \\
16 \\
17 \\
20 \\
20 \\
23\end{array}$ & $\begin{array}{r}1 \\
\mathbf{2} \\
\mathbf{2} \\
\mathbf{2} \\
\mathbf{3} \\
4 \\
\mathbf{3} \\
4 \\
14 \\
3 \\
0 \\
4 \\
0\end{array}$ & $\begin{array}{l}2 \\
\mathbf{2} \\
\mathbf{3} \\
\mathbf{3} \\
4 \\
\mathbf{3} \\
4 \\
4 \\
4 \\
\mathbf{5} \\
6 \\
7 \\
7\end{array}$ & $\begin{array}{l}14.9 \\
17.1 \\
12.3 \\
15.4 \\
15.1 \\
13.9 \\
14.1 \\
15.4 \\
13.0 \\
13.8 \\
15.6 \\
13.8 \\
12.2\end{array}$ & $\begin{array}{c}\text { Very good } \\
\text { Do. } \\
\text { Do. } \\
\text { Do. } \\
\text { Do. } \\
\text { Do. } \\
\text { Do. } \\
\text { Do. } \\
\text { Do. } \\
\text { Do. } \\
\text { Questionable } \\
\text { Do. } \\
\text { Do. }\end{array}$ \\
\hline 15 & 4 & $221^{\circ} \mathrm{F}$ & $\begin{array}{r}5 \\
5 \\
8 \\
8 \\
11 \\
11 \\
11 \\
14 \\
14 \\
16 \\
17 \\
20 \\
20\end{array}$ & $\begin{array}{r}0 \\
1 \\
3 \\
4 \\
2 \\
4 \\
1 \\
3 \\
14 \\
2 \\
2 \\
8\end{array}$ & $\begin{array}{r}2 \\
2 \\
3 \\
4 \\
3 \\
4 \\
6 \\
5 \\
6 \\
10 \\
5 \\
8\end{array}$ & $\begin{array}{r}10.0 \\
12.4 \\
14.5 \\
9.1 \\
16.9 \\
12.2 \\
13.0 \\
13.2 \\
13.7 \\
10.8 \\
11.5 \\
11.6\end{array}$ & $\begin{array}{l}\text { Good } \\
\text { Do. } \\
\text { Very good } \\
\text { Questionable } \\
\text { Very good } \\
\text { Do. } \\
\text { Good } \\
\text { Very good } \\
\text { Good } \\
\text { Questionable } \\
\text { Good } \\
\text { Questionable }\end{array}$ \\
\hline 20 & 3 & $226^{\circ} \mathrm{F}$. & $\begin{array}{r}5 \\
5 \\
8 \\
8 \\
11 \\
11 \\
13 \\
14 \\
17 \\
17 \\
19 \\
20\end{array}$ & $\begin{array}{r}4 \\
4 \\
1 \\
3 \\
1 \\
2 \\
14 \\
2 \\
0 \\
2 \\
15 \\
1\end{array}$ & $\begin{array}{l}2 \\
2 \\
3 \\
3 \\
3 \\
4 \\
5 \\
4 \\
6 \\
7 \\
7 \\
6\end{array}$ & \begin{tabular}{r|}
16.7 \\
8.3 \\
17.8 \\
14.5 \\
14.1 \\
12.9 \\
18.9 \\
15.5 \\
15.4 \\
13.2 \\
16.0 \\
16.2
\end{tabular} & $\begin{array}{l}\text { Very good } \\
\text { Good } \\
\text { Very good } \\
\text { Good } \\
\text { Very good } \\
\text { Good } \\
\text { Very good } \\
\text { Do. } \\
\text { Good } \\
\text { Questionable } \\
\text { Good } \\
\text { Do. }\end{array}$ \\
\hline
\end{tabular}


papayas. In thelye peeling of whole green papayas, best results were obtained when the papayas were used at the rate of 1 pound for each gallon of lye solution used. It also was found that the average loss in weight of papayas as stems and seeds was 9 percent.

TABLE 4.-Results from experiments with hand-peeled papayas

\begin{tabular}{c|c|c|c|c|c|c|c}
\hline $\begin{array}{c}\text { Experiment } \\
\text { number }\end{array}$ & Papayas & $\begin{array}{c}\text { Weight } \\
\text { of the } \\
\text { papayas }\end{array}$ & $\begin{array}{c}\text { Peeled } \\
\text { pulp } \\
\text { obtained }\end{array}$ & $\begin{array}{c}\text { Stems } \\
\text { and } \\
\text { seeds }\end{array}$ & Peels & $\begin{array}{c}\text { Total loss as } \\
\text { stems, seeds, } \\
\text { and peels }\end{array}$ & $\begin{array}{c}\text { Average } \\
\text { weight } \\
\text { per } \\
\text { papaya }\end{array}$ \\
\cline { 2 - 7 } & Number & Pounds & Percent & Percent & Percent & Percent & Pounds \\
1 & 6 & $291 / 2$ & 73.5 & 8.5 & 18.0 & 26.5 & 4.9 \\
2 & 5 & $201 / 2$ & 74.2 & 9.8 & 16.0 & 25.8 & 4.1 \\
3 & 5 & $208 / 4$ & 73.5 & 10.8 & 15.7 & 26.5 & 4.2 \\
4 & 7 & $251 / 4$ & 69.3 & 10.9 & 19.8 & 30.7 & 3.6 \\
5 & 6 & 24 & 71.8 & 9.4 & 18.8 & 28.2 & 4.0 \\
6 & 7 & $288 / 4$ & 77.4 & 5.2 & 17.4 & 22.6 & 4.1 \\
7 & 6 & $261 / 4$ & 75.3 & 7.6 & 17.1 & 24.7 & 4.4 \\
8 & 6 & $251 / 2$ & 76.5 & 7.8 & 15.7 & 23.5 & 4.3 \\
9 & 7 & $248 / 4$ & 76.7 & 8.1 & 15.2 & 23.3 & 3.5 \\
10 & 8 & 28 & 77.7 & 8.0 & 14.3 & 22.3 & 3.5 \\
11 & 8 & $271 / 2$ & 76.3 & 8.2 & 15.5 & 23.7 & 3.4 \\
12 & 8 & $271 / 4$ & 78.0 & 7.3 & 14.7 & 22.0 & 3.4 \\
13 & 7 & $301 / 2$ & 80.2 & 6.6 & 13.2 & 19.8 & 5.0 \\
14 & 7 & $268 / 4$ & 77.6 & 8.4 & 14.0 & 22.4 & 3.8 \\
15 & 7 & $271 / 2$ & 75.6 & 8.2 & 16.4 & 24.6 & 3.9 \\
16 & 8 & 30 & 75.0 & 9.2 & 15.8 & 25.0 & 3.8 \\
\hline Average values & - & - & 75.5 & 8.4 & 16.1 & 24.5 & 3.9 \\
\hline
\end{tabular}

TABLE 5.-Pilot plant lye-peeling operation of papayas using a 15-percent lye solution and a 5 -minute immersion time

\begin{tabular}{c|c|c|c|c|c}
\hline $\begin{array}{c}\text { Experiment } \\
\text { No. }\end{array}$ & $\begin{array}{c}\text { Weight of } \\
\text { the papayas }\end{array}$ & $\begin{array}{c}\text { Peeled pulp } \\
\text { obtained }\end{array}$ & $\begin{array}{c}\text { Stems and } \\
\text { seeds }\end{array}$ & $\begin{array}{c}\text { Peel lost in } \\
\text { lye-peeling }\end{array}$ & $\begin{array}{c}\text { Total logt } \\
\text { in lye-pecling } \\
\text { plus stems } \\
\text { and seeds }\end{array}$ \\
\hline & Pounds & Percent & Percent & Percent & Percent \\
1 & 288 & 73.0 & 11.9 & 15.1 & 27.0 \\
2 & $1181 / 2$ & 73.4 & 9.3 & 17.3 & 26.6 \\
3 & $1611 / 2$ & 73.1 & 8.5 & 18.4 & 26.9 \\
4 & $1581 / 2$ & 74.5 & 8.8 & 16.7 & 25.5 \\
5 & $1371 / 4$ & 75.4 & 8.4 & 16.2 & 24.6 \\
6 & $918 / 4$ & 73.0 & 9.3 & 17.7 & 27.0 \\
\hline Average values & $9551 / 2$ & 73.8 & 9.4 & 16.8 & 26.2 \\
\hline
\end{tabular}




\section{RESUMEN}

Al revisar la literatura no se encontró información alguna sobre las condiciones más adecuadas para pelar la papaya usando soluciones de soda cáustica. Los experimentos realizados con otras frutas y vegetales sugirieron la conveniencia de investigar este aspecto del problema para determinar las relaciones correctas entre la concentración de la soda caústica y el tiempo de inmersión requerido para pelar la fruta.

En este trabajo se uś un tanque rectangular de acero, dividido en el medio para formar dos cámaras. Una de las cámaras contenía la solución de soda cáustica y la otra, el agua para el lavado de la fruta tratada con soda. El tanque tenía una cabida máxima funcional para 17 galones de solución.

Para el lavado de la papaya, la fruta se vació en un canasto de acero perforado, el canasto se sumergí luego en la cámara que contenía la solución de soda en ebullición y al terminar el tiempo prescrito para la inmersión, el canasto se sacó y se sumergió inmediatamente en la cámara con agua fría, donde fue que se removió la cáscara digerida por la soda.

La papaya (Carica papaya L.) que se usó en estos experimentos se obtuvo de un predio experimental sembrado en la Subestación de Gurabo y de plantaciones comerciales en el área de Isabela. Es bueno señalar que las variedades comerciales que se siembran actualmente en Puerto Rico no son de un tipo fijo, pues varían en tamaño, forma, color y espesor de la pulpa. El peso promedio de las frutas que se usaron fluctuó entre 3 y 5 libras.

Los resultados obtenidos de estos experimentos indican que cuando se pelan las papayas verdes y enteras es una solución de soda cáustica, debe aplicarse uno de los tres tratamientos siguientes: Inmersión durante 6 minutos en una solución en ebullición de soda cáustica al 10 por ciento; inmersión durante 4 minutos en una solución en ebullición de soda cáustica al 15 por ciento; o inmersión por 3 minutos en una solución en ebullición de soda cáustica al 20 por ciento, por peso. La pérdida que se atribuye a la cáscara en cada uno de los tres tratamientos recomendados fue de 14.2, 11.6 y 11.5 por ciento, por peso, respectivamente. Los cambios en la acidez que pueden evaluarse y en la dureza de la pulpa de la papaya pelada con una solución de legía coinciden con los valores obtenidos para la pulpa de papaya pelada a mano. Existe una relación óptima entre el volúmen de la solución de legía y el peso de la papaya a pelarse. Los mejores resultados se obtuvieron cuando se trató la fruta a razón de 1 libra por galón de solución de soda cáustica. Las pruebas que se llevaron a cabo demuestran que la pérdida en el peso de la fruta que puede atribuirse a los tallos y semillas representa aproximadamente un 9 por ciento. 


\section{LITERATURE CITED}

1. Woodroof, J. G., Cecil, S. R., Shelor, E., and Cecil, Ida A., Peeling with lye, - J. Agr. Res. USDA 5(10): 1956-8, 1942.

2. Mazzola, L. C., New caustic peeling method reduces waste and saves labor, Food Ind. 15: 53, 1943.

3. Greig, W. S., and Manchester, A. C., Cost of peeling potatoes by lye and abrasive methods, Amer. Potato J. 85: 731, 1958.

4. Dunlop, R. L., Lye-peeling pays off, Food Ind. 16: 969, 1944.

5. Woodroof, J. G., and Atkinson, I. S., Preserving sweetpotatoes by freezing, Bull. 232, Ga. Expt. Sta., 1944.

6. - - Food Industries Manual, 19th ed., 695-7, Leonard Hill Books, London, England, 1962.

7. Stateler, E. S., Now-quick dehydration, Food Ind. 174(3): 1450-2, 1945. 